\title{
ANNONA SQUAMOSA L. (ANNONACEAE): CHEMICAL BIOPROSPECTION AND BIOLOGICAL ACTIVITY IN TWO PHENOLOGICAL STAGES
}

\author{
SILVA, I. T. S. S. ${ }^{1}-$ FERNANDES, M. J. B. ${ }^{2}-$ OliVEIRA, R. A. ${ }^{3}-$ CARVALHO, L. D. ${ }^{1}-$ \\ CORTEZ, P. A. ${ }^{1}-$ SÃo JOSÉ, A. R. ${ }^{4}$ - CONCEIÇÃO, A. O.* ${ }^{1}$ \\ ${ }^{1}$ Department of Biological Science, Universidade Estadual de Santa Cruz, Ilhéus, Bahia, Brazil \\ (phone:+1 5573 3680-5105; fax: +1 5573 3680-5230) \\ ${ }^{2}$ Center of Research and Development of Animal Health, Instituto Biológico, São Paulo, São \\ Paulo, Brazil (phone: +1 5511 fax: +1 5511 5087-1791)
}

${ }^{3}$ Department of Mathematical Sciences and Technology, Universidade Estadual de Santa Cruz, Ilhéus, Bahia, Brazil (phone:+1 5573 3680-5620; fax: +1 5573 3680-5230)

${ }^{4}$ Department of Animal and Plant Science, Universidade Estadual do Sudoeste da Bahia, Vitória da Conquista, Bahia, Brazil (phone:+1 5577 34237548; fax: +1 55077 3423-7038)

*Corresponding author

e-mail: aoconceicao@uesc.br; phone:+1 5573 36805105; fax: +1 5573 3680-5230

(Received 21 $1^{\text {st }}$ Apr 2016; accepted 16 ${ }^{\text {th }}$ Jun 2016)

\begin{abstract}
Annona squamosa L. has been recognized by having compounds with important in vitro biological activity against human disease or as insecticide. However, knowledge of the antiviral potential and micro molecules production of $A$. squamosa $\mathrm{L}$. at different phenological stages is scarce. The secondary metabolites detection and biological activity from seeds and leaves in 4 and 14 years old trees from semi arid region were performed. Phytochemical identification was obtained by chemical bioprospection and histochemical localization in leaves and seeds'. Seeds acids content was analyzed by gas chromatography. Cytotoxic effect and antiviral activities against equine and suid herpesvirus were also performed. Results showed differences in the amount of flavonoids, carotenoids, and phenolic compounds between leaves and seeds and by stage of production. Carotenoids and phenolic compounds, especially tannins, were higher in older trees' leaves. Fat acids detected in seeds were oleic, linoleic arachidic, Cis-11-eicosenoic, elaidic and palmitoidic acids. Cytotoxicity was higher in hydrophobic than hydroalcoolic extracts. Broad spectrum antiviral activity was more marked for younger trees' aqueous extract. The high chemical adaptability of A. squamosa to semi arid environment was evident and the identification of $A$. squamosa secondary metabolites regarding the plant senescence may guide a better utilization of plant organs in order to obtain substances of pharmacological interest.
\end{abstract}

Keywords: natural products, secondary metabolites, apoptosis, antiherpetic

\section{Introduction}

Annona squamosa L. (Annonaceae Juss.), popularly known as custard apple, frutado-conde, ata or pinha, is recognized as one of the most important traditional edible medicine tree as well as by its economical sustainability (São José et al., 2014; Maas et al., 2014). The medicinal usage of $A$. squamosa includes the treatment of hypertireoidism, cancer, and heart and infectious diseases. The tea from root is used as purgative and the powder of unripe fruit is used to treat worms and protozoa (Di stasi and Hiruma-Lima, 2003). The leaves' infusion is also used to treat ulcer, wounds and swoon, and the seeds are recognized by their pesticide effects (Gajalakshmi et al., 2011; Luna et al., 2015). Economically, A. squamosa crop has been characterized mainly by 
small farmers using the family labor and presents increasing important socio-economic values considering international market because of its status as exotic fruit showing excellent qualities (São José et al., 2014).

\section{Review of Literature}

Several secondary metabolites have been identified from Annonaceae species, including phenolic acids, tannins, flavonoids, benzenics compounds, lipids, proteins, lactones, vitamins, carotenes and saponins (Leboeuf et al., 1980). From A. squamosa leaves, two main chemical classes were described: steroids and terpenoids (Savithramma et al., 2011). Particularly, acetogenins and benzylisoquinoline alkaloids isolated from this family have received special attention due to their variety and distribution in Annonaceae representatives in distinct stages of development, including A. squamosa (Yogesh, 1994; Araya et al., 2002; De-La-Cruz et al., 2013).

In vitro studies have validated the medicinal potential of Annona secondary metabolites being Leishmanicidal (Vila-Nova et al., 2011), antioxidant (Panda and Kar, 2007; Mariod et al., 2012), antimicrobial (Padmaja et al., 1995; Rahma et al., 2005), and antitumoral (Tormo et al., 2001; Yang et al., 2009; Chen et al., 2012) activities most described in the literature. Also, hyperglycemiant properties of fat acids from seeds (Sultana, 2008), anti-HIV activity of diterpenes from A. squamosa (Wu et al., 1996), and anti-herpetic activity of ethanolic (Padmaja et al., 1995) and methanolic (BetancurGalvis et al., 1999) extracts from A. muricata were reported. More specifically, acetogenins isolated from Annona seeds demonstrated cytotoxicity (Vila-Nova et al., 2011) and immunosuppression related to antitumoral activity (Tormo et al., 2001; Araya et al., 2002; Yang et al., 2009; Chen et al., 2012).

The relation between biological potential of plants and the plant-environment interface is another point of interest in the A. squamosa studies. Seasonality, circadian cycle, ultraviolet radiation, and temperature, can be considered the main environmental factors involved in reducing and increasing the production rate of secondary metabolites (Taiz and Zeiger, 2008) since A. squamosa seems to show a greater control of transpiration through stomata closure in water deficit situation (Endres, 2007).

Although biological properties are evident, there is a lack of information about phytochemical prospection description, histochemical localization, and antiviral potential elucidation of $A$. squamosa tree which could guide the search for biologically active molecules. Consequently, in this study, two stage of cultivation of $A$. squamosa initial production stage (4 years) and peak production stage (14 years) - were chosen to better understand the variability on secondary metabolites of A. squamosa in semi arid environment and its influence on antiviral activity against suid (SHV-1) and equid (EHV-1) alphaherpesviruses.

\section{Materials and Methods}

\section{Botanical field collection}

The A. squamosa L., Annonaceae, mature leaves and fruits from both 4 and 14 years of cultivation where collected from a commercial rural property located in the municipality of Anage, Bahia state, Brazil (14²6.159' S; $\left.41^{\circ} 05.216^{\prime} \mathrm{WO}\right)$, where cultivation is monitored from seed germination. The environment where the plants 
grown is defined as caatinga area of Brazilian Northeast, characterized by a xeric shrubland (less dry) and thorny trees with an annual precipitation varying from 400 to $600 \mathrm{~mm}$. Plant material was identified and deposited at herbarium of Universidade Estadual Santa Cruz (HUESC) under register number HUESC\#18501 (http://inct.splink.org.br/) and identified by Prof. Luiz Alberto da Costa Matos. A. squamosa is not native from Brazil (Datiles and Acevedo-Rodriguez, 2016) and it is not considered an endangered or a protected plant once it is largely cultivated around the world.

\section{Extract production}

For extract production, leaves were submitted to dryness at $50^{\circ} \mathrm{C}$ under forced ventilation and reduced a powder with mechanical knifes. Seeds from several fruits were cleaned and dried at room temperature. Seeds (S) and leaves (L) powder were then submitted to aqueous (Aq), hexanic (Hex) and ethanolic (Et) extraction. The aqueous extract of leaves was done by infusion at $10 \%$ for 1 hour, filtered and lyophilized. The ethanolic extracts from seeds and leaves were obtained by exhaustive extraction, using $10 \mathrm{~g}$ of powder plant material in $100 \mathrm{~mL}$ of ethanol 99\% (Biotec, Brazil). The solvent was evaporated under reduced pressure and the extract recovered. The hexanic extract was obtained by Soxhlet method following the International Union of Pure ad Applied Chemistry (IUPAC) procedure with hexane for 6 hours. The solvent was evaporated under reduced pressure and the extract recovered. The ethanolic extracts were stored at $4^{\circ} \mathrm{C}$ in the dark while hexanic and lyophilized extracts were kept at room temperature in the dark.

For biological test, immediately before use, hexanic and ethanolic extracts were dissolved with $0.8 \mathrm{~mL}$ of dimethyl sulfoxide (DMSO, Sigma-Aldrich, Brazil) and Minimal Essential Medium (MEM - Vitrocell/Embriolife ${ }^{\circledR}$, Atená-SP) to obtain an 8 $\mathrm{mg} \cdot \mathrm{mL}^{-1}$ stock solution. Work solutions varied from 0.03 to $4 \mathrm{mg} \cdot \mathrm{mL}^{-1}$. Aqueous extracts were dissolved directly in MEM at the same stock and work solutions.

\section{Phytochemical prospection}

To perform phytochemical prospection, the NI 1600 UV-VIS spectophotometer (Novainstruments ${ }^{\circledR}$, São Paulo, Brazil) was used and all solutions were high purity quality.

\section{Carotenoid}

The carotenoids determination was performed according to the technique and equation described by Kimura and Rodriguez (2003). For that, to $0.3 \mathrm{~g}$ of plant powder material, $50 \mathrm{ml}$ of acetone was added. After 30 minutes the solution was vacuum filtered and $1.5 \mathrm{~mL}$ of clarifying solution $[1,5 \mathrm{~mL}$ de $\mathrm{Ba}(\mathrm{OH}) 2(0.3 \mathrm{M})$ e $1.5 \mathrm{~mL}$ de $\mathrm{ZnSO}_{4}(5 \%)$ ] was added and after 30 minutes, all solution was vacuum filtered again. Next, $30 \mathrm{~mL}$ of petroleum ether was added to the mixture directly in the filter funnel. The ether phase was harvested and exhaustively washed. The ether extract was then transferred to a volumetric flask and the $50 \mathrm{~mL}$ final volume was completed with petroleum ether. The ether extract was transferred to a $50 \mathrm{~mL}$ volumetric flask by adjusting the volume of solutions with petroleum ether. A $450 \mathrm{~nm}$ wave length was used to read samples. 


\section{Total phenolic compounds}

To determine phenolic compounds, the Folin-Ciocauteau reagent (RFC) was used following the method described by Wettasingue and Shahidi (1999) and Brito et al. (2013). To a final volume of $10 \mathrm{~mL}, 0.5 \mathrm{ml}$ of RFC, $0.5 \mathrm{~mL}$ of the plant extract and 1 $\mathrm{mL}$ of saturated $\mathrm{NaHCO}_{3}$ solution were added to water. After 25 minutes, the analysis at $773 \mathrm{~nm}$ wavelength was performed. Gallic acid (GA, $1 \mathrm{mg} . \mathrm{mL}^{-1}$ stock solution) was used to prepare an analytical curve varying from 5 to $217.5 \mu \mathrm{g} \cdot \mathrm{mL}^{-1}$. The analytical curve were made in triplicate and presented the equation $\mathrm{y}=0.0034 \mathrm{x}+0.0194$ with $\mathrm{R} 2=0.990$ being detection (DL) and quantification (QL) limit values of $1.973 \mu \mathrm{g} \cdot \mathrm{mL}^{-1}$ and $6.576 \mu \mathrm{g} . \mathrm{mL}^{-1}$, respectively. The total phenolic compounds were expressed in $\mathrm{mg}$ of GA equivalents per $100 \mathrm{~g}$ of dried plant.

\section{Flavonoid}

The quantification of flavonoid followed Sobrinho et al. (2008) procedures. In a 25 $\mathrm{mL}$ volumetric flask $1.0 \mathrm{~mL}$ of methanolic solution was added to the sample, followed by $0.6 \mathrm{~mL}$ glacial acetic acid (concentrated), $1 \mathrm{~mL}$ of methanolic piridin $(20 \% \mathrm{v} / \mathrm{v})$ and $2.5 \mathrm{~mL}$ methanolic $\mathrm{AlCl}_{3}\left(50 \mathrm{mg}\right.$. $\left.\mathrm{L}^{-1}\right)$, reaching a final volume with destiled water. After 30 minutes at room temperature, samples were detected by espectophotometry at $420 \mathrm{~nm}$ wave lenght. Rutine (RU, $0.5 \mathrm{mg} . \mathrm{mL}^{-1}$ stock solution) was used to prepare an analytical curve varing from 5 to $30 \mu \mathrm{g} \cdot \mathrm{mL}^{-1}$. The analytical curve were made in triplicate and presented the equation $\mathrm{y}=0.0075 \mathrm{x}+0.1, \mathrm{R} 20.998$ being detection (DL) and quantification (QL) limit values of $0.4799 \mu \mathrm{g} . \mathrm{mL}^{-1}$ and $1.599 \mu \mathrm{g} . \mathrm{mL}^{-1}$, respectively. The flavonoids content was expressed in $\mathrm{mg}$ of RU equivalents per $100 \mathrm{~g}$ of dried plant.

\section{Tannin}

The tannins content was determined following Tiitto-Julkunem (1985) procedures. For that, $0.5 \mathrm{~g}$ of sample was soaked in $30 \mathrm{~mL}$ of $80 \%$ aqueous acetone (80:20, PA acetone, water, v.v-1) under continuous stirring at room temperature $\left(24^{\circ} \mathrm{C} \pm 2^{\circ} \mathrm{C}\right)$ for 20 minutes. The mixture was filtered and another extraction was done. The procedure was repeated twice. Then, extractions were combined and $3 \mathrm{~mL}$ of a methanol solution of vanillin $(4 \% \mathrm{MV}-1)$ was added to the $50 \mathrm{~mL}$ final volume adjusted with water. Then, in a tube covered with aluminum foil, $0.5 \mathrm{~mL}$ of the extract was put together with $3 \mathrm{~mL}$ of vaniline methanolic solution $(4 \% \mathrm{w} / \mathrm{v})$ and $1.5 \mathrm{~mL}$ of concentrated $\mathrm{HCl}$. The mixture was stirred vigorously, and read at $500 \mathrm{~nm}$ wave length. Catechin $\left(25 \mathrm{mg} \cdot \mathrm{mL}^{-1}\right.$ stock solution) was used to prepare an analytical curve varying from 5 to $125 \mu \mathrm{g} \cdot \mathrm{mL}^{-1}$. The analytical curve were made in triplicate and presented the equation $\mathrm{y}=0.0024 \mathrm{x}+$ $0.2173, \mathrm{R} 2=0.9990$ being detection (DL) and quantification (QL) limit values of $0.62500 \mu \mathrm{g} . \mathrm{mL}-1$ and $2.0833 \mu \mathrm{g} . \mathrm{mL}^{-1}$, respectively. The tannins content was expressed as catechin equivalents per $100 \mathrm{~g}$ of dried plant.

\section{Histochemical localization}

Leaves and seeds of 4 and 14 years of cultivation of $A$. squamosa L. were selected for in situ localization of their main chemical compounds. Some fresh samples were cut by hand using a razor blade. Additionally, part of the samples were fixed in $2.5 \%$ glutaraldeyde, $4.0 \%$ formaldehyde and $0.2 \mathrm{M}$ cacodylate buffer solution, $\mathrm{pH} 7.2$ (modified from Karnovsky, 1965), embedded using the HistoResin Embedding Kit 
(Leica, Heidelberg, Germany) and sectioned using a RM 2145 rotary microtome (Leica, Heidelberg, Germany) with glass knife. All the sections obtained were mounted onto glass slides and submitted to specific tests, including their respective controls. All the analyses were made using a DM 2500 light microscope (Leica, Heidelberg, Germany) equipped with a DFC 295 digital camera (Leica, Heidelberg, Germany). Also, scanning electron microscopic (Quanta 250 (FEI Company) was used to verify micromorphological aspects of the the epidermal cells.

\section{Gas chromatography analysis from hexanic extract}

\section{Ester methyl production}

Three $\mathrm{mL}$ of hexane and $4 \mathrm{~mL}$ of $\mathrm{NaOH}(0.5 \mathrm{~N})$ methanolic solution were added to a $50 \mathrm{mg}$ of oil. The mixture was heated at $65-70^{\circ} \mathrm{C}$ for 3 to 5 minutes until total solubilization. After cooling down, $5 \mathrm{~mL}$ of transestherifing solution [ $\mathrm{NH} 4 \mathrm{Cl}(10 \mathrm{~g})$ in methanol $(300 \mathrm{~mL})+\mathrm{H}_{2} \mathrm{SO}_{4}$ concentrated $\left.(15 \mathrm{~mL})\right]$ and again heated at $65-70^{\circ} \mathrm{C}$. Five minutes later, the mixture was cooled down and transferred to a separation funnel, where $4 \mathrm{~mL}$ of $\mathrm{NaCl}$ saturated solution was added. The hexane phase was selected, stored under refrigeration and analyzed by GC.

\section{CG analysis}

The methyl ester were analyzed by gas chromatography using Varian Saturno 3800 equipped with flame ionized detector (FID) and melted silica capillary column (30 m x $0.25 \mathrm{~mm})$ with Carbowax (0.25 $\mu \mathrm{m}$ film thin) stationary phase, having helium as drag gas, flow of $1.0 \mathrm{~mL} /$ minute. The injector and detector temperatures were $220^{\circ} \mathrm{C} \mathrm{e}$ $240^{\circ} \mathrm{C}$, respectively. The column temperature began at $60^{\circ} \mathrm{C}$ and it was increased from $5^{\circ} \mathrm{C}$ to $200^{\circ} \mathrm{C}$, maintaining the latest for 5 minutes more. One $\mu \mathrm{L}$ of hexane phase (split 1:10) was injected. A fat acids certified standards mixture varying from 8 to 24 carbons (Sigma-Aldrich - USA) was used to identify the sample fat acids content by comparison. The fat acid methyl esters' concentrations were obtained through integral area of picks related to all sample components total area, normalized method.

\section{Biological assay}

Vero cell lines, (Vero, ATCC-CL 81) kindly provided by Instituto Butantan (São Paulo, Brazil), were used to perform cytotoxic and antiviral assays. Cells were cultivated in MEM supplemented with $8 \%$ of fetal bovine serum (FBS, Vitrocell/Embriolife ${ }^{\circledR}$, Atená) with $5 \% \mathrm{CO}_{2}$ atmosphere at $37^{\circ} \mathrm{C}$. For all tests, cells were seeded in a 96 well plate at $3.0 \times 10^{4}$ cell/well density. After $24 \mathrm{~h}$ seeding, cells were treated with different concentrations of extracts $(0.03 \mathrm{mg} \cdot \mathrm{mL}-1 \mathrm{a} 4 \mathrm{mg} \cdot \mathrm{mL}-1)$ and incubated at $5 \% \mathrm{CO}_{2}$ atmosphere and $37^{\circ} \mathrm{C}$ for $48-72 \mathrm{~h}$.

To verify citotoxicity of hexanic, ethanolic, and aqueous extracts, the 3-(4, 5-dimetilazol-2-il)-2,5-difeniltetrazolium bromide (MTT, Sigma-Aldrich, Brazil) mitochondrial reduction assay was used (Valadares et al., 2007). Also, cells were stained with May-Grünwald-Giemsa to analyze cell morphological changes.

The cytotoxic concentration to $50 \%$ of cell culture $\left(\mathrm{CC}_{50}\right)$ was calculated using GraphPad Prism version 7.00 for Windows, GraphPad Software, San Diego California USA (free trial version) and the maximum non cytotoxic concentration (MNCC) for this study was considered the concentration $50 \%$ below the $\mathrm{CC}_{50}$. 
For cytotoxic experiments, controls consisted of cells treated with MEM only, DMSO at $0.5 \%$ and DMSO at $1.25 \%$.

The antiviral activity assay was performed using suid alphaherpesvirus type 1 (SuHV-1; EMBRAPA: BRMSA 3, 00588 strain) and equid alphaherpesvirus type 1 (EHV-1; 4/72 strain). Due to high cytoxicity of some extracts, only aqueous extracts from seeds and leaves and hexanic extract from seeds were tested for antiviral activity. The methodology was adapted from Kaziyama et al. (2012). After $24 \mathrm{~h}$ seeding and $75 \%$ confluence of Vero cells, supernatants were removed and cells were treated with MNCC extracts and MNCC extracts with virus. Controls with only virus or cells were also used. Cells were incubated at $37^{\circ} \mathrm{C}$ and $5 \%$ de $\mathrm{CO}_{2}$ atmosphere for three days. Cytopathic effects (cell tumefaction and death) were observed every day and tissue culture infectious dose to $50 \%$ of the cell culture $\left(\right.$ TCID $_{50}$ ) was determined. The viral inhibition index (VII) was obtained through Reed and Muench (1938) method giving the proportional difference between viral titer from extract treated cells and not treated cells. Following criteria established by Simoni et al. (2007), the extract was antiviral eligible when VII was $\geq 1.5$ corresponding to percentage of inhibition (PI) of $97 \%$.

\section{Statistical analysis}

Student's $t$ test and one-way ANOVA, followed by Tukey's test were done. Statistical analyses were performed with the Prism software (version 7.00; GraphPad Software, 2007, San Diego, California, USA). All experiments samples were made in replicates and repeated at least three times.

\section{Results}

\section{Phytochemical prospection}

Phytochemical difference was seen between plant organ and tree age being carotenoides and flavonoids found in significatively higher amounts in leaves from older trees (Table 1). Also, phenolic compounds were found only in leaves of 14 years individuals with more then a half of components constituted by condensed tanins.

Table 1. A. squamosa L. leaf and seed chemical bioprospection according to two plant tree age. Anagé, Bahia State, Brazil, 2015.

\begin{tabular}{|c|c|c|c|c|}
\hline \multirow[b]{2}{*}{ Tree age (years) } & \multicolumn{2}{|c|}{ Leaves } & \multicolumn{2}{|c|}{ Seed } \\
\hline & 4 & 14 & 4 & 14 \\
\hline $\begin{array}{l}\text { Carotenoids } \\
\left(\mathrm{mg} .100 \mathrm{~g}^{-1}\right)\end{array}$ & $0.11 \mathrm{~b} * *$ & $0.29 \mathrm{a} * *$ & $0.011 \mathrm{~B} * *$ & $0.014 \mathrm{~A} * *$ \\
\hline $\begin{array}{l}\text { Flavonoids } \\
\left(\mathrm{mg} 100 \mathrm{~g}^{-1}\right)\end{array}$ & $240.37 b *$ & $488.25 \mathrm{a}^{*}$ & $21.06 \mathrm{~A} *$ & $12.13 \mathrm{~A} *$ \\
\hline $\begin{array}{l}\text { Total phenols } \\
\left.\text { (mg.g } \mathrm{g}^{-1} \mathrm{GAE}\right)\end{array}$ & ND & 562.25 & ND & ND \\
\hline $\begin{array}{l}\text { Condensed tannins } \\
\left(\mathrm{mg} 100 \mathrm{~g}^{-1}\right)\end{array}$ & ND & 343.98 & ND & ND \\
\hline
\end{tabular}




\section{Histochemical localization}

Through histochemical technique plant metabolites such as alkaloids, lipids, phenolic compounds, terpenoids, and starch were located in leaves and seeds from both 4 and 14 years trees (Table 2). The differences observed were more at plant organ level then at phenological stage, highlighting the presence of acid lipid and starch only in seeds and phenolic compounds in leaves.

Table 2. Histochemical analysis of Annona squamosa seeds and leaves regarding two plant tree ages.

\begin{tabular}{lcccc}
\hline & \multicolumn{2}{c}{ Leaves } & \multicolumn{2}{c}{ Seeds } \\
\cline { 2 - 5 } & 4 years & 14 years & 4 years & 14 years \\
\hline Alkaloid & + & + & + & + \\
Total lipid (Sudan) & + & + & + & + \\
Acid lipid & - & - & + & + \\
Structural phenolic compounds & + & + & - & - \\
Total phenolic compounds & + & + & - & - \\
Terpenoids (essential oil) & + & + & + & + \\
Terpenoids (resinified acid) & + & + & + & + \\
Starch & - & - & + & + \\
\hline
\end{tabular}

Presence of compound (+); Compound not detected (-)

In situ localization associated to scanning electron microscopy technique revealed the micromorphological aspects of the wax covering all the epidermal cells, including those which form the stomata apparatus (Fig. 1A). In leaves, the results showed the presence of total lipids in the mesophyll idioblast (Fig. 1B) and essential oil in the petiole cortex idioblast (Fig. 1C) (Fig. 1D). Tannic Acid and Ferric Chloride reaction revelead the presece of mucin in the larger mesophyll idioblasts as well as condensed tannin in the idioblasts of the mesophyll main vein (Fig. 1E). In seeds, total lipids (Fig. $1 F$ ), acid resin (Fig. 1G), essential oil and oilresin (Fig. 1H) were detected in the endosperm cells. In this same plant organ, alkaloids were detected only in some peripheral endosperm cells (Fig. II-J). 

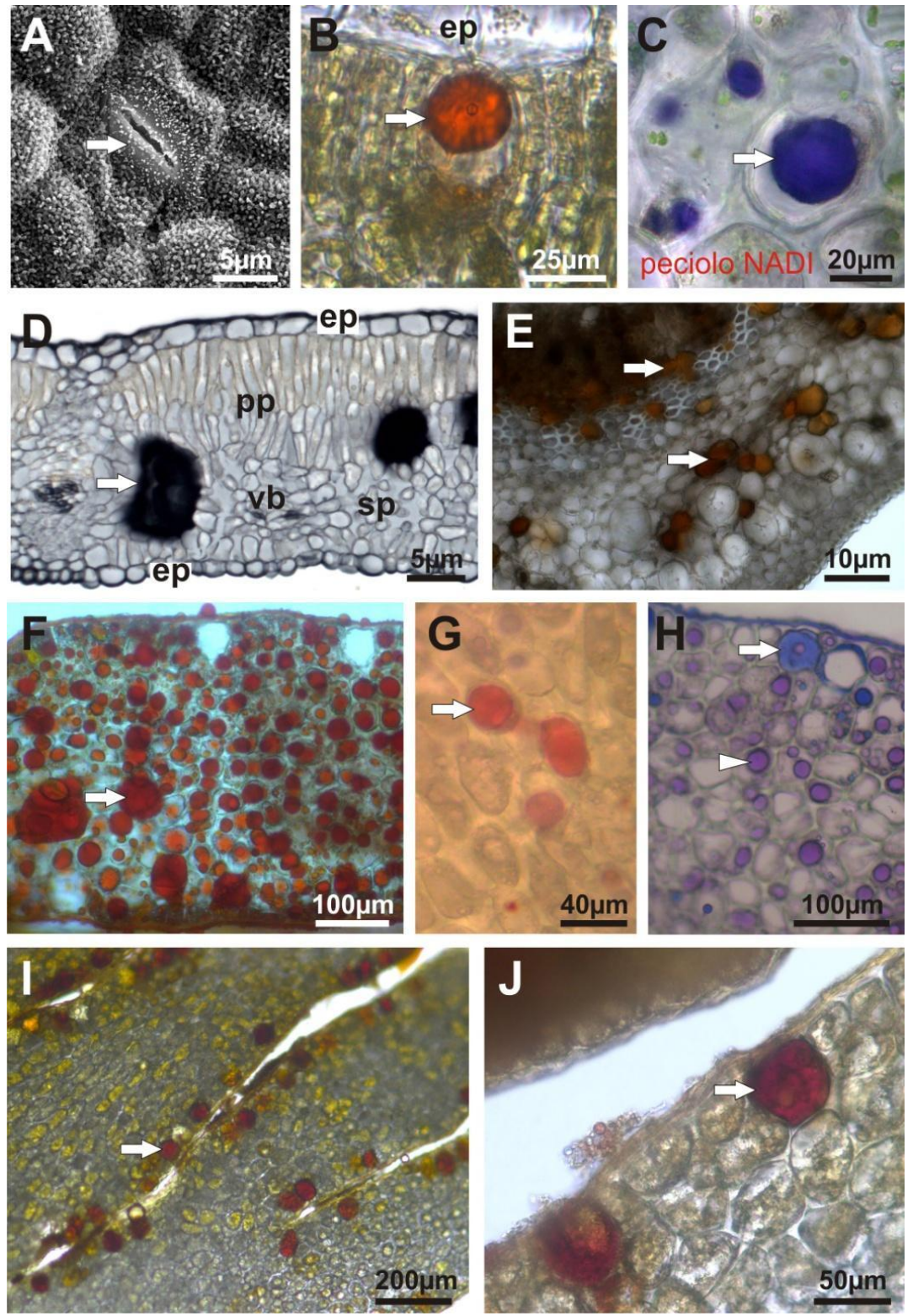

Figure 1. In situ localization of the major chemical compounds detected in the A. squamosa L. leaves (A-E) and seeds (F-J). (A) Scanning electron microscopy technique revealing the micro morphological aspects of the wax covering all the epidermal cells, including those which form the stomata apparatus (arrow). (B) Sudan IV test showing positive result for total lipids in the mesophyll idioblast (red color, arrow). (C) NADI reaction showing positive result for essential oil in the petiole cortex idioblast (blue color, arrow). (D) Tannic Acid and Ferric Chloride reaction showing positive result for mucin in the larger mesophyll idioblasts (black color, arrow). (E) Chlorine Vanillin reaction showing positive result for condensed tannin in the idioblasts of the mesophyll main vein (reddish orange color, arrows). (F) Sudan IV test showing positive result for total lipids in the endosperm cells (red color, arrow). (G) NADI reaction showing positive result for acid resin in the endosperm cells (red color, arrow). (H) NADI reaction showing positive result for essential oil (blue color, arrow) and for oilresin (purple color, arrowhead) in the endosperm cells. (I, J) Dittmar (I) and Wagner (J) reactions showing positive result for alkaloids in peripheral endosperm cells (reddish orange color, arrow). Symbols: ep=epidermis; $p p=$ palisade parenchyma; sp=spongy parenchyma; vb=vascular bundle. 


\section{Gas chromatography}

To elucidate lipid compounds detected in seeds by qualitative analysis, gas chromatography was performed from hexanic extraction (Table 3). The majority of fat acids analyzed had similar amount considering the two tree ages studied. However, differences were found between tree age in relation to arachidic acid and Cis-11eicosenoic acid contents, being this compound found only in older trees seed.

Table 3. A.squamosa fat acids from seed hexanic extraction by gas chromatography analysis according to two plant tree age. Anage, Bahia State, Brazil, 2015.

\begin{tabular}{|c|c|c|c|c|c|}
\hline \multirow{2}{*}{$\begin{array}{l}\text { A. squamosa tree age } \\
\text { Methyl esters standards }\end{array}$} & \multicolumn{3}{|c|}{4 years } & \multicolumn{2}{|c|}{14 years } \\
\hline & $\mathbf{R T}^{1}$ & $\mathbf{R T}^{2}$ & $\begin{array}{c}\text { Content } \\
(\%)\end{array}$ & $\mathbf{R T}^{2}$ & $\begin{array}{l}\text { Content } \\
(\%)\end{array}$ \\
\hline Palmitoleic acid (C16: 1n9-c) & 22,080 & 22,101 & 6.20 & 22,141 & 7.50 \\
\hline Elaidic acid $(\mathrm{C} 18: \ln 9 \mathrm{t})$ & 25,606 & 25,627 & 16.04 & 25,695 & 11.55 \\
\hline Oleic acid (C18: 1n9C) & 25,941 & 25,956 & 52.72 & 26,080 & 49.50 \\
\hline Linoleic acid (C18: 2n6-c) & 26,651 & 26,676 & 21.78 & 26,760 & 25.80 \\
\hline Arachidic acid (C20: 0) & 27,655 & ND & ND & 27,698 & 0.98 \\
\hline Cis-11-eicosenoic acid (C20: 1) & 28,857 & ND & ND & 28,905 & 1.37 \\
\hline
\end{tabular}

\section{Biological assay}

The biological assay results indicated the more functional plant organ and phenological stage regarding antiviral activity potential. Significant differences between phenological stages was not seen, however compounds extraction had a role in the toxicity. In relation to antiviral activity, a difference in virus sensibility was seen. In general, SuHV-1 was more sensitive than EHV-1, including an unusual elevation on virus titer observed. Exception was seen for 14 years tree aqueous extract from seeds which was more active against EHV-1. Regarding compounds selected, aqueous extraction from leaves showed the best effect. Finally, with exception of the seeds aqueous extract for EHV-1, the tree age did not play a significant role in antiviral activity when comparing same extraction solvent (Table 4).

Table 4. Cytotoxic concentration $\left(C_{50}\right)$, Viral inhibition index (VII) and percentage of inhibition (PI) of A. squamosa extracts, obtained from two plant tree age against SuHV-1 and $E H V-1$.

\begin{tabular}{ccccccc}
\hline Plant Extracts & Tree age & CC $_{\mathbf{5 0}}$ & \multicolumn{2}{c}{ SuHV-1 } & \multicolumn{2}{c}{ EHV-1 } \\
& & [mg.mL $^{-\mathbf{1}}$ ] & IIV & PI (\%) & IIV & PI (\%) \\
\hline LAq & 4 & 0.32 & 0.55 & 71.60 & 0.60 & 74.88 \\
& 14 & 0.42 & 0.50 & 68.38 & 0.59 & 68.86 \\
SAq & 4 & 1.43 & -0.16 & -46.78 & 0.00 & 0.00 \\
& 14 & 1.51 & 0.17 & 32.91 & 0.50 & 53.58 \\
SHex & 4 & 0.49 & 0.50 & 68.38 & 0.13 & 25.87 \\
& 14 & 0.40 & 0.25 & 44.02 & 0.39 & 37.77
\end{tabular}

$\mathrm{CC}_{50}-50 \%$ cytotoxic concentration for cell culture. LAq - leaves aqueous extract; $\mathrm{SHex}-$ seeds hexane extract; SAq - seeds aqueous extract. 


\section{Discussion}

The genus Annona has been studied by its biological potential in health and agriculture. In this study some secondary metabolites and biological activity of seed and leaves extracts obtained from A. squamosa are reported. Differences in cultivation stage and plant organ were seen. Through bioprospecting, mainly secondary metabolites such as carotenoids, phenolic compounds including flavonoids and condensed tannins were detected and quantified in leaves and seeds (Table 1). The histochemical localization analyses allowed identifying plant organ and the cell types in which the major chemical compounds were produced and stored (Table 2, Fig. 1). Palmitoleic, elaidic, oleic, linoleic, arachidic, and cis-11-eicosenoic acids were also identified and quantified in seeds hexanic extract by gas chromatography (Table 3$)$.

Carotenoids content was significantly higher $(\mathrm{p}<0.01)$ in leaves and seeds of 14 years trees when compared to 4 years ones. Carotenoid levels usually remain constant in leaves until early senescence (Uenojo et al., 2007), however an increase during ripening can be seen, at which there is an intensification of the synthesis of this compound (John et al., 1970). Here, the higher content found is in accordance with the stage of production of older trees at the moment of collection. Moreover, the high content of carotenoids may be connected to photo protection process against oxidative damage in function of the adaptability to climate (Taiz and Zeiger, 2008; Mertz et al., 2009). It is worth to note that there is a tendency to recover this metabolite from the leaves instead of seeds, since the amount of this metabolite was very close to lower detection limit by the method used. Naturally, regarding to photo protection, seeds are protected by fruit tissues.

The presence of phenolic compounds in A. squamosa leaves has been already reported (Mariod et al., 2012), however differences between trees of different stage of production is one notable point of our study. Flavonoids were significantly higher $(\mathrm{p}<0.5)$ in leaves of 14 years individuals when compared with plants in the beginning of fruit production (4 years). Total phenolic compounds were observed only in leaves of 14 years production $\left(562.25 \mathrm{mg} \mathrm{GAE} . \mathrm{g}^{-1}\right)$, and it is worth to note that from total phenolic compounds, $343.98 \mathrm{mg} \cdot 100 \mathrm{~g}^{-1}$ were condensed tannins. The sites of tannin production were the large cells located in the leaf mesophyll, where its protective feature became evident against the UV radiation damage (Wang et al., 2014) and herbivory (Lokvam and Kursar, 2005). Interestingly, phenolic substances such as flavonoids and tannins have allelopathic function contributing to the establishment of seedlings photo protection and plant adaptability along their development (Waterman and Mole, 1994; Giner-Chaves, 1996; Rawat et al., 1998; Hassanpour et al., 2011). In this study, the microclimate adaptability, more specifically the high incidence of sunshine in the semiarid area, lead us to think that the amount found in older trees is due to protection against oxidative stress or as accessory pigments on photosynthesis (Hassanpour et al., 2011).

The fat acids from $A$. squamosa seeds deserve attention for their quantitative and qualitative variation, being considered the seeds as the main lipid storage organ (Corner, 1949). The fat acids in the seeds where histologically detected in almost every endosperm cells, which are the main storage tissue of the Annonaceae species (Kessler, 1993). In this context, differences in fat acids content have been reported in relation to seeds stage of development representing the potential of the plant to plasticity (Endres, 2007; Chacón et al., 2013). In this study, an expressive amount of polyunsaturated fat acids (PUFAs) such as oleic and linoleic acids were detected in seeds from both tree age of production. However, arachidic and Cis-11-eicosenoic acids were detected only in 
seeds of later production stage (14 years) and higher amount of elaidic and palmitoidic acids were detected in seeds of initial production stage (4 years) trees. Although less expressive, the fat acids from leaf where derived from the epidermal wax, a layer that is related to the dry protection among other functions (Samuels et al., 2008), and also from some mesophyll and petiole cells, reinforcing the great importance of this class of compounds to plant adaptation.

As plant metabolism reflects its plasticity, the variety of secondary metabolites originated from this adaptation gives to the vegetal a great potential for biological proposals. In this study, cytotoxicity and antiviral tests were biological properties explored for A. squamosa biological potential. The cytotoxic morphological findings confirmed the potential of A. squamosa compounds to cause apoptotic effects on tumoral cells (Pardhasaradhi et al., 2005). Cells treated with hexanic and aqueous extracts showed apoptosis signs characterized by reduction of cell volume, nuclear fragmentation, and the presence of apoptotic bodies (Table 4 and Fig. 2). It was also noted that aqueous extract from leaves were more toxic than aqueous extract from seeds (Tables 4 and 5) which is in agreement with their tannins content. Although tannins have biological properties, they can be very harmful to mammalian cells and removing them from extract can help other phenolic compounds to positively act on infection agents and in the mammalian systems as reported elsewhere (Schmitt et al., 2001; Hassanpour et al., 2011; George et al., 2012; Zhao and Hu, 2013). Furthermore, the high cytotoxicity of hexane extract from seeds and ethanolic extracts from seeds and leaves was verified in our study.

The antiviral activity of Annona extracts is an additional biological activity not yet described in the literature. However these data confirmed the antiviral potential of the Annona species, following the criteria established by Simoni et al. (2007), the antiviral activity of $A$. squamosa extracts was considered weak. Both viruses tested seemed to be sensitive to water-soluble compounds such as tannins, for which inhibition related to virus protein interaction has been reported in the literature Kikulskie et al. (1992). On the other hand, it is worth to note that although some flavonoids have already been identified as anti-herpetic (Cushnie and Lamb, 2005; Lin et al., 2011; Kumar and Pandey, 2013), in the 4 years trees seeds aqueous extracts, which are rich in flavonoides, there was no antiviral activity on EHV-1. In addition, in our study, the influence of some A. squamosa products on SuHV-1 cell interaction seen by enhanced virus titer (\%PI of $-46.78 \%$ ) should receive more attention in the future.

Analyzing the effect of hexanic extracts from seeds against both viruses it seems to confirm the interaction between virus and PUFAs reported in the literature (Apostolov et al., 1989; Leu et al. 2004; Orhan et al., 2011). For example, the pretreatment of cells with extracts having oleic and linoleic acid as major compounds, lead to maximal antiviral effect against hepatitis $\mathrm{C}$ virus (HCV) (Oh and Chung, 2014). In addition, the elaidic acid has shown promising action against herpesvirus compared to gancyclovir (Andrei et al., 2000) and it was found in A. squamosa seeds reported here. Finally, the stronger action of seeds' hexanic extracts from 4 years trees compared to 14 years trees on SuHV-1 indicate a potentiating on antiviral action in the absence of arachidic and, or eicosanoic acid.

Finally, the great diversity of secondary metabolites provides plants distinct therapeutic properties. One point of concern is to have substances of interest at qualitative and quantitative level at the right moment of plant's life. Thereby, through a chemical and biological approach, the diversity of substances in seeds and leaves of two 
different ages of $A$. squamosa showed the adaptation of these plants to the hostile condition of a xeric shrub land and thorn forest environment and indicated the leaves of plants in the beginning of production (4 years) as the suitable ones to obtain biological potential directed to viral-natural products interaction. Besides those chemical compounds analyzed here, we considered the importance of the alkaloids and mucilaginous substances, which are detected by our histological evaluation in the seeds and leaves, respectively. We emphasize that these kinds of metabolites are often related with the protection for plants that grown in dry environments (Di Stasi and HirumaLima, 2003) and has some pharmacological properties (Gajalakshmi et al., 2011) and, for these, deserve accurate attention.

Acknowledgements. This work was financially supported by the Fundação de Amparo a Pesquisa da Bahia fund (PET-0058/2012) and Coordenação de Aperfeiçoamento de Pessoal de Nivel Superior (CAPES) for ITSS scholarship. The authors thank Electronic Microscopic Center and Laboratory of Anatomy from Universidade Estadual de Santa Cruz.

\section{REFERENCES}

[1] Andrei, G., Snoeck, R., Neyts, J., Sandvold, M.L., Myhren, F., De Clercq, E. (2000): Antiviral activity of ganciclovir elaidic acid ester against herpesviruses. - Antiviral Research 45:157-167.

[2] Apostolov, K., Barker, W., Galpin, S.A., Habib, N.A., Wood, C.B., Kinchington, D. (1989): Syncytia formation in HIV-1 infected cells is associated with an increase in cellular oleic acid. - FEBS Letters 250:241-244.

[3] Araya, H., Sahai, M., Singh, S., Singh, A.K., Yoshida, M., Hara, N., Fujimoto, Y. (2002): Squamocin-O1 and squamocin-O2, new adjacent bis-tetrahydrofuran acetogenins from the seeds of Annona squamosa. - Phytochemistry 61:999-1004.

[4] Betancur-Galvis, L.A., Saez, J., Granados, H., Salazar, A., Ossa, J.E. (1999): Antitumor and Antiviral Activity of Colombian Medicinal Plant Extracts - Memorias do Instituto Oswaldo Cruz 94:531-535.

[5] Brito, N, Amarante Junior, O, Polese, L, Ribeiro, M. (2003): Validação de métodos analíticos: Estratégias e dicussão. - Pesticida R. Ecotoxicologia e Meio Ambiente13:129_ 146.

[6] Chen, Y, Chen, JW, Wang, Y, Xu, SS, Li, X. (2012): Six cytotoxic annonaceous acetogenins from Annona squamosa seeds. - Food Chemistry135:960-966.

[7] George, V.C., Kumar, D.R., Rajkumar, V., Suresh, P.K., Kumar, R.A. (2012): Quantitative assessment of the relative antineoplastic potential of the n-butanolic leaf extract of Annona Muricata Linn. in normal and immortalized human cell lines. - Asian Pacific Journal of Cancer Prevention 13:699-704.

[8] Corner, E. (1949): The annonaceous seed and its four integuments. - New Phytology 48:332-64.

[9] Cushnie, T.P., Lamb, AJ. (2005): Antimicrobial activity of flavonoids. - International Journal of Antimicrobial Agents 26: 343-356.

[10] Datiles, M.J., Acevedo-Rodriguez, P. (contributers) (2016): Invasive Species Compendium - Annona aquamosa (sugar apple). In: http://www.cabi.org/isc/datasheet/5820. Accessed in 11 jun, 2016.

[11] Chacón, I. D.-C., Riley-Saldaña, C.A., González-Esquinca, A.R. (2013): Secondary metabolites during early development in plants. - Phytochemistry Reviews 12: 47-64.

[12] Di Stasi, L.C., Hiruma-Lima, C.A. (2003): Medicinal plants in the Amazon and Atlantic Forest. 2 nd. Stasi LC Di, Hiruma-Lima CA, editors. UNESP. 
[13] Endres, L. (2007): Daily and seasonal variation of water relationship in sugar apple (Annona squamosa L.) under different irrigation regimes at semi-arid Brazil. Scientia Horticulturae 113: 149-154.

[14] Gajalakshmi, S., Divya, R., Deepika, V.D., Mythili, S., Sathiavelu, A. (2011): Pharmacological activities of Annona squamosa: a Review Taxonomic Classification. International Journal of Pharmaceutical Sciences Review and Research 10:24-29.

[15] Giner-Chaves, B.I. (1996): Condensed tannins in tropical forages. Cornell University, Ithaca, NY.

[16] Hassanpour, S., Maherisis, N., Eshratkhah, B., Baghbani Mehmandar, F. (2011): Plants and secondary metabolites (Tannins): A Review. - International Journal of Forest, Soil and Erosion (IJFSE) 1:47-53.

[17] John, J., Subbarayan, C., Cama, H.R. (1970): Carotenoids in 3 stages of ripening of mango. - Journal of Food Science 35:262-265.

[18] Kaziyama, V., Fernandes, M., Simoni, I. (2012): Antiviral activity of commercially available medicinal plants on suid and bovine herpesviruses. - Brazilian Journal of Medicina Plants 14:522-528.

[19] Kimura, M., Rodriguez-Amaya, D.B. (2003): Carotenoid composition of hydroponic leafy vegetables. - Journal of Agriculture and Food Chemistry 51:2603-2607.

[20] Kumar, S., Pandey, A.K. (2013): Chemistry and biological activities of flavonoids: An overview. - The Scientific World Journal. ScientificWorld Ltd.

[21] Leboeuf, M., Cavé, A., Bhaumik, P.K., Mukherjee, B., Mukherjee, R. (1980): The phytochemistry of the annonaceae. - Phytochemistry. 21: 2783-2813.

[22] Leu, G.Z., Lin, T.Y., Hsu, J.T.A. (2004): Anti-HCV activities of selective polyunsaturated fatty acids. - Biochemical and Biophysical Research Communications 318:275-280.

[23] Lin, L.-T., Chen, T.-Y., Chung, C.-Y., Noyce, R.S., Grindley, T.B., McCormick, C., Wang GH, Lin, C.C., Richardson, C.D. (2011): Hydrolyzable tannins (chebulagic acid and punicalagin) target viral glycoprotein-glycosaminoglycan interactions to inhibit herpes simplex virus 1 entry and cell-to-cell spread. Journal of Virologt 85:4386-4398.

[24] Luna, J.S., Santos, A.F., Lima, M.R.F., Omena, M.C., Mendonça, F.A.C., Bieber, L.W., Sant'Ana, A.E.G. (2005): A study of the larvicidal and molluscicidal activities of some medicinal plants from northeast Brazil. - Journal of Ethnopharmacology 97:199-206.

[25] Mace, M.E., Howell, C. R. (1974): Histochemistry and identification of condensed tannin precursors in roots of cotton seedlings. - Canadian Journal of Botany 52:24232426.

[26] Maas, P., Lobao, A., Rainer, H. (2014): Annonaceae in Species List flora of Brazil. Botanical Garden of Rio de Janeiro [Internet]. [cited 2014 Jan 1]. Available from: http://floradobrasil.jbrj.gov.br/jabot/floradobrasil/FB110219.

[27] Mariod, A.A., Abdelwahab, S.I., Elkheir, S., Ahmed, Y.M., Fauzi, P.N.M., Chuen, C.S. (2012): Antioxidant activity of different parts from Annona squamosa, and Catunaregam nilotica methanolic extract. - Acta scientiarum Polonorum / Technologia alimentaria 11:249-258.

[28] Mertz, C., Gancel, A.L., Gunata, Z., Alter, P., Dhuique-Mayer, C., Vaillant, F., Perezc, A.M., Rualesd, J., Brata, P. (2009): Phenolic compounds, carotenoids and antioxidant activity of three tropical fruits. - Journal of Food Composition and Analysis 22:381-387.

[29] Oh, M., Chung, M.S. (2014): Effects of Oils and Essential Oils from Seeds of Zanthoxylum schinifoliumagainst Foodborne Viral Surrogates. - Evidence-Based Complementary and Alternative Medicine 2014:135797 (6 pages).

[30] Orhan, İ., Özçelik, B., Şener, B. (2011): Evaluation of antibacterial, antifungal, antiviral, and antioxidant potentials of some edible oils and their fatty acid profiles. _ Turkish Journal of Biology 35:251-258.

[31] Padmaja, V., Thankamany, V., Hara, N., Fujimoto, Y., Hisham, A. (1995): Biological activities of Annona glabra. - Journal of Ethnopharmacology 48:21-24. 
[32] Panda, S., Kar, A. (2007): Antidiabetic and antioxidative effects of Annona squamosa leaves are possibly mediated through quercetin-3-O-glucoside. - Biofactor 31:201-210.

[33] Pardhasaradhi, B.V.V., Reddy, M., Ali, A.M., Kumari, A.L., Khar, A. (2005): Differential cytotoxic effects of Annona squamosa seed extracts on human tumour cell lines: role of reactive oxygen species and glutathione. - Journal of Bioscience 30:237244.

[34] Pearse, A.G.E. (1980): Histochemistry: theoretical and applied. - Churchill Livingstone, London.

[35] Pizzolato, T., Lillie, R. (1973): Mayer's tannic acid-ferric chloride stain for mucins. Journal of Histochemistry and Cytochemistry 21:56-64.

[36] Rahman, M.M., Parvin, S., Haque, M.E., Islam, M.E., Mosaddik, M.A. (2005): Antimicrobial and cytotoxic constituents from the seeds of Annona squamosa. Fitoterapia 76: 484-489.

[37] Rawat, M., Pant, B., Prasad, D., Joshi, R.K., Pande, C.P. (1998): Plant growth inhibitors (Proanthocyanidins) from Prunus armeniaca. - Biochemical Systematic and Ecology 26: 13-23.

[38] Reed, L.J., Muench, H. (1938): A simple method of estimating fifty per cent endpoints. American Journal of Epidemiology. - Oxford University Press 27:493-497.

[39] São José, A.R., Pires, M.M., Freitas, A.L.G.E., Ribeiro, D.P., Perez, L.A.A. (2014 ): Atualidades e perspectivas das Anonáceas no mundo. - Revista Brasileira de Fruticultura 36: 86-93.

[40] Savithramma, N., Linga Rao, M., Suhrulatha, D. (2011): Screening of Medicinal Plants for Secondary Metabolites. - Middle-East Journal of Scientific Research 8:579-584.

[41] Schmitt, A.C., Ravazzolo, A.P., Von Poser, G.L. (2001): Investigation of some Hypericum species native to Southern of Brazil for antiviral activity. - Journal of Ethnopharmacology 77:239-245.

[42] Simoni, I. (2007): Evaluation of the antiviral activity of Brazilian cerrado plants against animal viruses. - Virus Review and Research 12:25-31.

[43] Sobrinho, T.J.S.P., Silva, C.H.T.P., Nascimento, J.E., Monteiro, J.M., Albuquerque, U.P., Amorim, E.L.C. (2008): Validação de metodologia espectrofotométrica para quantificação dos flavonóides de Bauhinia cheilantha (Bongard) Steudel. - Revista Brasileira de Ciências Farmacêuticas 44:683-689.

[44] Sultana, N. (2008): Lipoxygenase inhibition by novel fatty acid ester from Annona squamosa seeds. - Journal of Enzyme Inhibition and Medicinal Chemistry 23:877-881.

[45] Taiz, L., Zeiger, E. (2008): Fisiologia Vegetal. - Artemed, Porto Alegre.

[46] Tormo, J.R., Estornell, E., Gallardo, T., González, M.C., Cavé, A., Granell, S., ZafraPolo, M.C. (2001): $\gamma$-lactone-functionalized antitumoral acetogenins are the most potent inhibitors of mitochondrial complex I. - Bioorganic and Medicinal and Chemistry Letters 11:681-684.

[47] Uenojo, M., Marostica, J., Pastore, G.M. (2007): Carotenoids: Properties, applications and biotransformation in flavor compounds. - Quim Nova 30:616-622.

[48] Valadares, M. C., Castro, N. C., Cunha, L. C. (2007): Synadenium umbellatum: citotoxicidade e danos ao DNA de células da medula óssea de camundongos. - Brazilian Journal of Pharmaceutical Sciences 43:631-638.

[49] Vila-Nova, N.S., Morais, S.M., Falcão, M.J.C., Machado, L.K.A., Beviláqua, C.M.L., Costa, I.R.S., Gramosa, N.V, Brasil, PS., Andrade Junior, H.F. (2011): Leishmanicidal activity and cytotoxicity of compounds from two Annonacea species cultivated in Northeastern Brazil. - Revista da Sociedade Brasileira de Medicina Tropical 44: 567-571.

[50] Waterman, P.G., Mole, S. (1994 ): Analysis of phenolic plant metabolites. - Blackwell Scientific Publications, Oxford.

[51] Wu, Y.C., Hung, Y.C., Chang, F.R., Cosentino, M., Wang, H.K., Lee, K.H. (1996): Identification of ent-16 beta, 17-dihydroxykauran-19-oic acid as an anti-HIV principle 
and isolation of the new diterpenoids annosquamosins A and B from Annona squamosa. Journal of Natural Product 59:635-637.

[52] Yang, H.-J., Li, X., Zhang, N., Chen, J.-W., Wang, M.-Y. (2009): Two new cytotoxic acetogenins from Annona squamosa. - Journal of Asian Natural Products Research 11:250-256.

[53] Fujimoto, Y., Murasaki, C., Shimada, H., Nishioka, S., Kakinuma, K., Singh, S., Singh, M., Gupta, Y.K., Sahai, M. (1994): Annonaceous Acetogenins from the Seeds of Annona squamosa.Non-adjacent Bis-tetrahydrofuranic Acetogenins. - Chemical and Pharmaceutical Bulletin 42:1175-1184.

[54] Zhao, B., Hu, M. (2013): Gallic acid reduces cell viability, proliferation, invasion and angiogenesis in human cervical cancer cells. - Oncology Letters 6:1749-1755. 